\title{
EFISIENSI PRODUKSI AYAM BROILER DI KECAMATAN RUMBAI KOTA PEKANBARU PROVINSI RIAU
}

\section{The efficiency of Broiler Chickens Production in Rumbai District Pekanbaru City Riau Province}

\author{
Elinur Elinur dan Sisca Vaulina \\ Prodi Agribisnis Fakultas Pertanian Unversitas Islam Riau \\ Email: elinurdjaimi@agr.uir.ac.id
}

\begin{abstract}
The research aims to analyse the level of production efficiency from technical, allocative and economic aspects. The research used survey method which is located in Rumbai district, Pekanbaru City. The research used cross section data which were obtained by personal interview. Samples were selected with using a simple random sampling method with a total of 40 broiler chicken breeders. Data Analysis used the Data Envelopment Analysis (DEA) technique. The result showed that broiler chicken breeders were technically efficient as much as 40 percent, and 12.5 percent were allocative and economically efficient. In general, broiler chicken breeders were not technically, allocative and economically efficient. The inefficiency of broiler chicken breeders are caused by in-optimal of using production factors of broiler chicken breeders.
\end{abstract}

Keyword: Broiler chicken breeders, Technically efficient, Allocative efficient and Economically efficient

\begin{abstract}
ABSTRAK
Penelitian ini bertujuan untuk menganalisis tingkat efisiensi produksi dari aspek teknis, alokatif dan ekonomi. Penelitian ini dilakukan dengan menggunakan metode survei yang berlokasi di Kecamatan Rumbai Kota Pekanbaru. Penelitian ini menggunakan data cross section yang diperoleh dengan menggunakan metode wawancara. Sampling metode menggunakan metode simple random sampling dengan 40 peternak ayam broiler. Analisis data menggunakan metode Data Enveloment Analysis (DEA). Hasil Penelitian menunjukkan peternak ayam efisien secara teknis sebanyak 40 persen, dan 12,5 persen efisien secara alokatif dan ekonomi. Pada umumnya petenak ayam broiler tidak efisien secara teknis, alokatif dan ekonomi. Inefisiensi peternak ayam broiler disebabkan belum optimal menggunakan faktor produksi.
\end{abstract}

Keyword: Peternak Ayam Broiler, Efisiensi Teknis, Efisiensi Alokatif, Efisiensi Ekonomi

\section{PENDAHULUAN}

Kegiatan usaha ayam broiler (ayam pedaging) merupakan bagian dari subsektor peternakan unggas, Pakage dkk. (2014), perlu dikembangkan dan dimanfaatkan secara optimal untuk kesejahteraan. Kegiatan usaha ayam broiler merupakan usaha peternakan yang menjanjikan. Beberapa keunggulan usaha ternak ayam adalah produksinya yang cukup cepat (32-35 hari), sehingga dapat memenuhi kebutuhan pasar dibandingkan dengan usaha ternak lainnya.
Keunggulan lainnya adalah permintaan ayam pedaging yang semakin meningkat karena peningkatan penduduk dan kebutuhan protein, siap dipotong pada usia muda serta menghasilkan kualitas daging berserat lunak.

Berkembang pesatnya usaha ternak ini didukung oleh semakin kuatnya industri hulu ayam broiler, seperti perusahaan pembibitan (Breeding Farm), perusahaan pakan ternak (Feed Mill), perusahaan obat hewan dan peralatan peternakan (Saragih, 2000). Majunya usaha tergantung dari pengelolaan manajemen usaha 
yang baik terletak pada kemampuan peternak. Peternak sebagai pengambil keputusan bisnis harus memiliki kompetensi yang baik dalam mengelola usaha seperti berproduksi, keuangan, tenaga kerja dan pemasaran. Selain itu, Wakhidati (2017), pengetahuan peternak yang beragam berhubungan dengan alokasi input produksi. Appleby dkk (1992), Battese dan Rao (2002), pemahaman mengenai alokasi input tentu berkaitan erat dengan hasil produksi dan efisiensi usaha. Dalam berproduksi, usaha ayam broiler membutuhkan faktor produksi (input). Secara teori berproduksi membutuhkan faktor produksi seperti kapital, tenaga kerja dan bahan baku (Sugiarto dkk, 2010). Kapital merupakan barangbarang modal yang dapat meningkatkan produksi, seperti mesin, alat-alat pertanian dan bangunan perusahaan. Tenaga kerja yang digunakan bisa tenaga manusia. Bahan baku dapat diartikan sebagai input yang dapat meningkatkan produksi. Pada sektor pertanian bahan baku yang dimaksud adalah benih/bibit, jumlah pupuk, dan obatobatan. Dengan demikian produksi ayam broiler membutuhkan input berupa tenaga kerja, kandang, bibit ayam (DOC), pakan, obatan dan vitamin.

Dalam berproduksi seorang peternak dapat menggunakan dan mengkombinasikan faktor produksi ayam dengan efisien. Penggunaan faktor produksi yang efisien dapat menghasilkan keuntungan yang maksimum, sehingga usaha ayam tidak rugi. Rita (2009) dan Sumiarsih (2018), perlu adanya upaya-upaya peternak untuk mengalokasikan faktor-faktor produksi lebih efisien agar bisa mencapai hasil produksi yang optimum.

Permasalahan yang dihadapi oleh peternak saaat ini adalah harga pakan dan doc yang cenderung meningkat, sehingga peternak belum mampu menggunakan dan mengkombinasikan faktor produksi dengan efisien. Berdasarkan hal tersebut, tujuan peneltian ini untuk menganalisis tingkat efisiensi produksi ayam broiler pada masing-masing peternak ayam broiler dari aspek teknis, alokatif dan ekonomi.

\section{METODE PENELITIAN}

Penelitian ini menggunakan metode survey, yang berlokasi di Kecamatan Rumbai, Kota Pekanbaru, Provinsi Riau. Pemilihan lokasi penelitian dengan pertimbangan Kecamatan Rumbai memiliki populasi ayam terbesar di Kota Pekanbaru. Populasi penelitian ini berjumlah 202 peternak yang aktif mengelola usaha peternakan ayam broiler di Kecamatan Rumbai. Metode pengambilan sampel secara acak sederhana (Sample Random Sampling). Jumlah sampel sebanyak 20 persen dari populasi peternak ayam broiler (40 peternak) yang berada pada 5 kelurahan di Kecamatan Rumbai, terdiri dari (1) Kelurahan Umban Sari, (2) Kelurahan Rumbai Bukit, (3) Kelurahan Muara Fajar, (4) Kelurahan Palas, dan (5) Kelurahan Sri Meranti.

Penelitian ini menggunakan data cross section yang diperoleh dengan mewawancarai peternak ayam broiler dengan menggunakan kuesioner. Data tersebut meliputi identitas responden, penggunaan faktor produksi, biayabiaya usaha, produksi dan keuntungan peternak ayam broiler.

Analisis data menggunakan Data Envelopment Analysis (DEA). DEA adalah alat analisis data untuk menentukan efisiensi relatif dari unit pengambilan keputusan (DMU) Rahimi et al (2012); Mashkoor et al (2010); Pourjafar et al (2012). Pada penelitian ini, DEA digunakan untuk menjawab tingkat efisiensi teknis, alokatif dan ekonomi. Perhitungan efisiensi produksi tersebut menggunakan pendekatan output. Dalam artian meningkatkan produksi yang maksimum dengan menggunakan faktor produksi yang efisien. Metode DEA menggunakan pendekatan VRS yang mengasumsikan UKE/Peternak belum berproduksi pada skala optimum karena adanya keterbatasan biaya produksi dan produktivitas dari faktor produksi yang digunakan. Efisiensi teknis, alokatif (harga) dan efisiensi ekonomi tercapai apabila nilainya sama dengan 1 dan kecil dari 1 berarti tidak efisien.

\section{HASIL DAN PEMBAHASAN}

Efisiensi produksi adalah kemampuan peternak menghasilkan output pada suatu tingkat kualitas tertentu dengan biaya yang lebih rendah. Dalam ilmu ekonomi konsep efisiensi penggunaan faktor produksi dibedakan dalam 3 hal, yaitu efesiensi teknis, efesiensi alokatif (harga), dan efesiensi ekonomis (Soekartawi, 1997 dan Coelli et al, 1998). 
Metode DEA merupakan metode untuk menganalisis efisiensi relatif dari suatu unit pengambilan keputusan (peternak) yang bertanggung jawab terhadap penggunaan sejumlah input untuk memperoleh suatu output yang ditargetkan. DEA merupakan pemograman fraksional yang mencakup banyak output dan input. Efisiensi realtif yang diukur tersebut merupakan pengukuran mengukur suatu Unit Kegiatan Ekonomi (UKE) dibanding dengan UKE lain dalam sampel yang menggunakan jenis input dan output yang sama (Charnes, et.al (1978), Banker, et.al (1984) dalam Amanda, 2010).

Nilai efisiensi relatif dalam metode DEA berkisar antara 0 dan 1. Dalam metode DEA. Decision Making Unit (DMU) atau Unit Pembuat Keputusan (UPK) atau unit kegiatan ekonomi (UKE) adalah peternak. UKE atau DMU dikatakan efisien apabila nilai efisiensi teknis, alokatif dan ekonomi (rasio perbandingan antara output terhadap faktor produksinya) bernilai 1 . Sebaliknya, tidak efisien jika bernilai 0 . Nilai efisiensi 0, artinya DMU/UKE/Peternak tersebut melakukan pemborosan penggunaan faktor produksi, dan atau tidak mampu berproduksi pada penggunaan output yang optimal. Sebaliknya nilai efisiensi 1 berarti DMU/UKE/Peternak tersebut penggunaan faktor produksi secara optimal, sehingga mampu berproduksi maksimum. Perhitungan efisiensi menggunakan metode DEA dengan pendekatan VRS yang menghasilkan nilai efisiensi untuk masing-masing peternak ayam broiler.

\section{Efisiensi Teknis}

Efisien teknis merupakan besaran yang menunjukkan perbandingan antara produksi sebenarnya dengan produksi maksimum. Perhitungan efisiensi dilakukan dengan menghitung Marginal Physical Product (MPP) dari masing-masing factor produksi. MPP adalah perubahan output yang diakibatkan oleh adanya perubahan satu unit input. Proporsi nilai efisiensi dan inefisien teknis peternak disajikan pada Gambar 1.

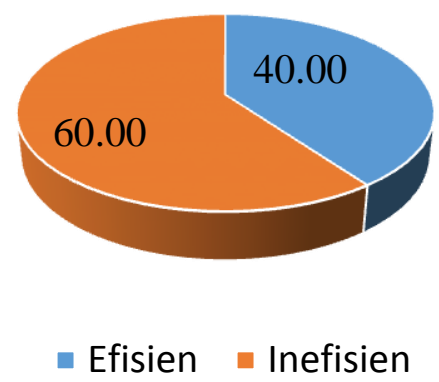

Gambar 1. Proporsi Efisiensi dan Inefisiensi Teknis Peternak Ayam Broiler di Kecamatan Rumbai Kota Pekanbaru (Tahun 2019).

Berdasarkan Gambar 1 dapat dijelas bahwa 40 persen peternak ayam broiler efisien secara teknis dalam mengelola usahataninya, sisanya 60 persen inefisiensi dalam mengelola usahatani tersebut. Nilai efisiensi teknis peternak berkisar antara 0 dan 1 . Nilai efisiensi teknis yang terkecil sebesar 0,91, yaitu peternak sampel ke-37 dan nilai efisiensi teknis peternak yang tertinggi sebesar 1 sebanyak 16 peternak, yaitu peternak sampel ke 1,3, 4, 6, 7, 10, 12, 16, 21, 22, 23, 25, 29, 30, 34 dan 40. Nilai efisiensi teknis rata-rata peternak ayam broiler sebesar 0,97 persen. Hal ini bermakna setiap penambahan 1 unit faktor-faktor produksi akan meningkatkan produksi ayam sebesar 0,97 persen, cateris paribus.

Efisiensi teknis dapat juga dilihat pada masing-masing desa. Data tingkat efisiensi teknis peternak ayam broiler pada masing-masing disajikan pada Tabel 1.

Tabel 1. Tingkat Efisiensi Teknis Peternak Ayam Broiler di Kecamatan Rumbai, Tahun 2019

\begin{tabular}{clccccc}
\hline \multirow{2}{*}{ No } & \multicolumn{5}{c}{ Efisiensi Teknis } \\
\cline { 2 - 6 } & Kelurahan & Tertinggi & Terendah & Rataan & Efisiensi (\%) & Inefisiensi (\%) \\
\hline 1 & Umban Sari & 1,00 & 0,93 & 0.96 & 50,00 & 50,00 \\
2 & Rumbai Bukit & 1,00 & 0,90 & 0,97 & 55,56 & 44,44 \\
3 & Muara Fajar & 1,00 & 0,94 & 0,97 & 25,00 & 75,00 \\
4 & Palas & 1,00 & 0,90 & 0,97 & 38,10 & 61,90 \\
5 & Sri Meranti & 1,00 & 0,97 & 0,97 & 25,00 & 75,00 \\
\hline
\end{tabular}


Tabel 1 menjelaskan bahwa banyak peternak yang tidak efisien secara teknis mencapai 44,44\%-75,00\%. Peternak ayam broiler yang efisien secara teknis sebanyak 16 orang dengan proporsi berkisar 25,00\%-55,56\%. Kelurahan Umban Sari dan Rumbai Bukit merupakan tingkat efisiensi yang tertinggi dibandingkan dengan desa lainnya. Kelurahan Muara Fajar dan Sri Meranti merupakan tingkat inefisiensi terendah. Demikian dapat dikatakan bahwa pada umumnya peternak ayam broiler tidak efisien secara teknis. Banyaknya peternak yang tidak efisien terjadi karena peternak tersebut tidak menggunakan kombinasi faktor produksi yang optimal. Praditia dkk. (2015), rendahnya efisiensi teknis tersebut disebabkan penggunaan faktor produksi seperti pakan, obat, vitamin, listrik, tenaga kerja tidak efisien.

\section{Efisiensi Alokatif}

Efisiensi alokatif (harga) merupakan ukuran tingkat keberhasilan peternak dalam usaha untuk mencapai keuntungan yang maksimum. Efisiensi harga tercapai pada saat nilai produksi marjinal setiap faktor produksi sama dengan harga faktor produksi tersebut $(\mathrm{VMPxi}=\mathrm{MFC})$. Dengan kata lain efisiensi harga menunjukkan kemampuan peternak untuk menggunakan faktor produksi yang optimal pada masing-masing tingkat harga dan teknologi tertentu. Peternak dikatakan efisien secara alokatif apabila peternak mampu menghasilkan output dengan biaya seminimal mungkin dengan menggunakan faktor produksi yang optimal. Proporsi efisiensi alokatif peternak ayam broiler yang efisien dan inefisien disajikan pada Gambar 2.

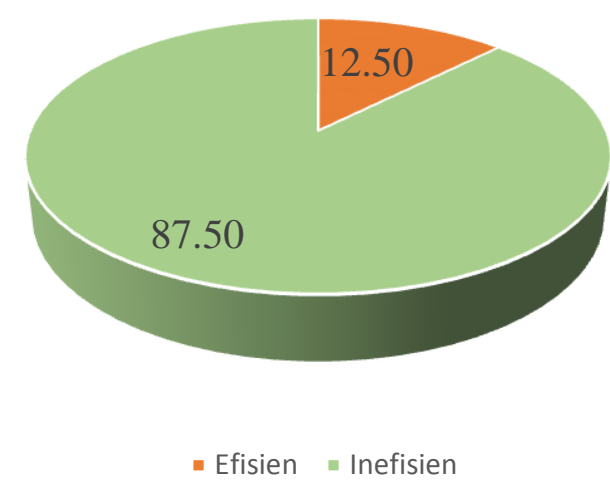

Gambar 2. Proporsi Efisiensi dan Inefisiensi Alokatif Peternak Ayam Broiler di Kecamatan Rumbai Kota Pekanbaru Tahun 2019

Gambar 2 menunjukkan bahwa 12,50 persen peternak ayam broiler efisien secara alokatif dalam mengelola usahataninya, sisanya 87,50 persen inefisiensi dalam mengelola usahatani tersebut. Nilai efisiensi alokatif peternak berkisar antara 0 dan 1 . Nilai efisiensi alokatif yang terkecil sebesar 0,01 , yaitu peternak sampel ke-2. Nilai efisiensi alokatif peternak yang tertinggi sebesar 1 sebanyak 5 peternak, yaitu peternak sampel ke 4, 6, 7, 12 dan 29. Nilai efisiensi alokatif rata-rata peternak ayam broiler sebesar 0,38 persen. Hal ini bermakna setiap penambahan 1 unit faktor-faktor produksi akan meningkatkan produksi ayam broiler sebesar 0,38 persen, cateris paribus.

Efisiensi alokatif dapat juga dilihat pada masing-masing kelurahan. Data tingkat efisiensi alokatif peternak ayam broiler pada masingmasing kelurahan disajikan pada Tabel 2.

Tabel 2. Tingkat Efisiensi Alokatif Peternak Ayam Broiler di Kecamatan Rumbai Tahun 2019.

\begin{tabular}{clccccc}
\hline \multirow{2}{*}{ No } & \multicolumn{5}{c}{ Efisiensi Alokatif } \\
\cline { 2 - 6 } & Kelurahan & Tertinggi & Terendah & Rataan & Efisiensi (\%) & Inefisiensi (\%) \\
\hline 1 & Umban Sari & 0,26 & 0,01 & 0.15 & 0,00 & 100,00 \\
2 & Rumbai Bukit & 1,00 & 0,18 & 0,50 & 33,33 & 66,67 \\
3 & Muara Fajar & 1,00 & 0,21 & 0,47 & 25,00 & 75,00 \\
4 & Palas & 1,00 & 0,16 & 0,36 & 4,76 & 95,24 \\
5 & Sri Meranti & 0,32 & 0,14 & 0,22 & 0,00 & 100,00 \\
\hline
\end{tabular}


Tabel 2 menjelaskan bahwa banyak peternak yang tidak efisien secara alokatif dengan tingkat capaian berkisar $66,67 \%-100,00 \%$.

Proporsi peternak ayam broiler yang efisien secara alokatif berkisar 00,00\%-33,33\%. Kelurahan Rumbai Bukit dan Muara Pajar merupakan tingkat efisiensi yang tertinggi dibandingkan dengan kelurahan lainnya. Kelurahan Umban Sari dan Sri Meranti merupakan tingkat inefisiensi terendah. Demikian dapat dikatakan bahwa pada umumnya peternak ayam broiler tidak efisien secara alokatif. Banyaknya peternak yang tidak efisien terjadi karena peternak tersebut tidak menggunakan kombinasi faktor produksi yang optimal dengan biaya produksi yang rendah (minimisasi cost).

\section{Efisiensi Ekonomi}

Efisiensi ekonomi diartikan apabila sumberdaya yang digunakan sebaik mungkin untuk menghasilkan keuntungan maksimum. Pada pasar persaingan terbuka efisiensi ekonomi terjadi apabila nilai produksi marginal (Value Marginal Product, VMP) sama dengan harga input. Hal ini berlaku pada kondisi tanpa batasan (kendala). Cara lain efisiensi dapat dinyatakan dengan tingkat substitusi teknik marginal (Marginal Rate of Subsitution, MRTS) antara pasangan input dengan rasio harganya. Ini berlaku untuk optimasi dengan kendala (Tasman, 2008).

Dalam penelitian ini efisiensi ekonomi diperoleh dengan pendekatan VRS dimana peternak belum berproduksi pada skala optimum karena adanya keterbatasan biaya produksi dan produktivitas dari faktor produksi yang digunakan. Dengan demikian peternak ayam broiler berproduksi dihadapkan dengan kendala produktivitas dari faktor produksinya. Proporsi efisiensi ekonomi peternak ayam broiler yang efisien dan inefisien disajikan pada Gambar 3.

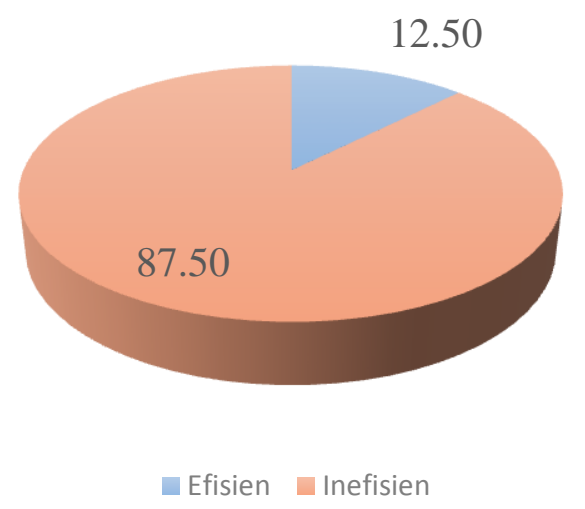

Gambar 3. Proporsi Efisiensi dan Inefisiensi Ekonomi Peternak Ayam Broiler di Kecamatan Rumbai Kota Pekanbaru Tahun 2019.

Gambar 3 menunjukkan bahwa 12,50 persen peternak ayam broiler efisien secara ekonomi dalam mengelola usahataninya, sisanya 87,50 persen inefisiensi dalam mengelola usahatani tersebut. Nilai efisiensi tersebut peternak berkisar antara 0 dan 1 . Nilai efisiensi ekonomi yang terkecil sebesar 0,01, yaitu peternak sampel ke-2 dan 9. Nilai efisiensi ekonomi peternak yang tertinggi sebesar 1 sebanyak 5 peternak, yaitu peternak sampel ke 4, 6, 7, 12 dan 29. Nilai efisiensi alokatif rata-rata peternak ayam broiler sebesar 0,38 persen. Hal ini bermakna setiap penambahan 1 unit faktor-faktor produksi akan meningkatkan produksi ayam broiler sebesar 0,38 persen, cateris paribus.

Efisiensi ekonomi dapat juga dilihat pada masing-masing kelurahan. Tingkat efisiensi ekonomi peternak ayam broiler pada setiap kelurahan disajikan pada Tabel 3.

Tabel 3. Tingkat Efisiensi Ekonomi Peternak Ayam Broiler di Kecamatan Rumbai Tahun 2019

\begin{tabular}{clccccc}
\hline \multirow{2}{*}{ No } & \multicolumn{5}{c}{ Efisiensi ekonomi } \\
\cline { 2 - 6 } & Kelurahan & Tertinggi & Terendah & Rataan & Efisiensi (\%) & Inefisiensi (\%) \\
\hline 1 & Umban Sari & 0,26 & 0,01 & 0,14 & 0,00 & 100,00 \\
2 & Rumbai Bukit & 1,00 & 0,01 & 0,49 & 33,33 & 66,67 \\
3 & Muara Fajar & 1,00 & 0,20 & 0,46 & 25,00 & 75,00 \\
4 & Palas & 1,00 & 0,14 & 0,36 & 4,76 & 95,24 \\
5 & Sri Meranti & 0,32 & 0,14 & 0,17 & 0,00 & 100,00 \\
\hline
\end{tabular}


Tabel 3 menunjukkan rataan nilai efisiensi ekonomi berkisar antara 0,14-0,49. Kelurahan Rumbai Bukit, Muara Fajar dan Palas mencapai nilai efisiensi ekonomi tertinggi karena memiliki nilai efsiensi ekonomi 1 . Terdapat 5 orang peternak yang memiliki nilai efisiensi ekonomi. Nilai efisiensi ekonomi 1 berarti peternak tersebut efisien secara teknis dan alokatif. Berbeda hal dengan Kelurahan Umban Sari dan Sri Meranti. Kelurahan Umban Sari dan Sri Meranti tidak ada peternak efisien secara ekonomi, karena nilai tertinggi masih dibawah 1. 100 persen jumlah petani tidak efisien secara ekonomi. Ketidakcapaian ini terjadi karena peternak tersebut tidak efisien secara ekonomi. Fattah (1999), penggunaan sumber daya secara efisien dapat meningkatkan produktivitas dan pendapatan masyarakat secara optimal, karena tanpa efisiensi masyarakat tidak dapat bersaing dipasar.

Berdasarkan uraian tersebut dapat disimpulkan bahwa pada umumnya petani tidak efisien secara ekonomi, karena tidak banyak peternak mencapai nilai efisiensi teknis dan alokatif sebesar 1. Ketidakefisiensi ini disebabkan peternak tersebut memiliki keterbatasan sumberdaya, teknologi dan pengetahuan (Tasman, 2008). Ketidakefisiensi ini menimbulkan jurang (yield gap) antara hasil aktual petani dengan hasil di lingkungan eksperimen. Perbedaan ini akan menimbulkan 2 yield gap. Yiel Gap 1 adalah perbedaan hasil antara hasil dalam lingkungan percobaan dengan hasil potensial dalam pertanian. Perbedaan ini disebabkan oleh perbedaan lingkungan dan teknologi non-transferable. Yield gap 2 adalah perbedaan hasil antara hasil potensial dalam pertanian dengan hasil aktual pertanian. Perbedaan ini disebabkan hambatan biologis dan sosioekonomi. Hambatan biologis seperti varietas, perumputan, penyakit dan hama tanaman, pengairan dan kesuburan tanah dan hambatan sosioekonomi terdiri dari biaya produksi dan tingkat pengembalian hasil, kredit, tradisi dan perilaku, pengetahuan, ketersediaan input dan institusi (kelembagaan petani) (Gomes et all 1979 dalam Tasman 2008).

Mahjoor (2013), peternakan ayam pedaging memiliki potensi besar untuk meningkatkan profitabilitas apabila peternak optimal pada efisiensi teknis, alokasi, dan ekonomi. Omar (2014), jika para petani tidak efisien, output dapat ditingkatkan dengan biaya yang lebih rendah melalui penyuluhan dan pendidikan.

\section{KESIMPULAN}

Berdasarkan pemaparan bagian-bagian terdahulu yang telah diuraikan maka dapat ditarik suatu simpulan, sebagai berikut:

1. Tingkat efisiensi teknis peternak ayam broiler tercapai berkisar antara $0,9-1,00$. Terdapat 40 persen atau sebanyak 16 orang peternak ayam broiler yang efisien secara teknik.

2. Tingkat efisiensi alokatif peternak ayam broiler berkisar antara 0,01-1,00. Terdapat 12,50 persen atau 6 orang peternak ayam broiler yang efisien secara alokatif.

3. Tingkat efisiensi ekonomi peternak ayam broiler berkisar antara 0,01-1,00. Terdapat 12,50 persen atau 6 orang peternak ayam broiler yang efisien secara ekonomi.

\section{DAFTAR PUSTAKA}

Appleby, M.C., Hughes, B.O, dan Elson, H.E. 1992. Poultry Production Systems. Behaviour, Management and Welfare. CAB International, UK.

Battese, G.E. dan Rao, D.S.P. 2002. Technology Gap, Efficiency, and a Stochastic Metafrontier Function. International Journal of Business and Economics, 1(2): 87-93

Coelli T, D.S.P. Rao., and Battese G.E. 1998. An Introduction to Efficiency and Productivity Analys. Kluwer Academic Publisher, London

Heriyanto, H. and Darus, D., 2017. Analisis

Efisiensi Faktor Produksi Karet di

Kabupaten Kampar Provinsi Riau. Dinamika Pertanian, 33(2), pp.1-10.

Heriyanto, H., Asrol, A., Karya, D. and Ningsih, V.Y., 2018. Analisis Faktor

Produksi Kalapa Sawit Rakyat Menurut Tipologi Lahan di Kabupaten Indragiri Hilir Provinsi Riau. Jurnal Lahan Suboptimal, 7(1). 
Heriyanto, H., Karya, D., Choanji, T., Asrol, A., Bakce, D. and Elinur, E., 2019. Regression Model in Transitional Geological Environment For Calculation Farming and Production of Oil Palm Dominant Factor in Indragiri Hilir

Riau Province. Journal of Geoscience, Engineering, Environment, and Technology, 4(1), pp.56-65.

Heriyanto, H. (2016). Perilaku Konsumsi Pangan Sumber Karbohidrat Rumahtangga Petani Kelapa Sawit Di Kecamatan Kandis Kabupaten Siak. Jurnal Ilmiah Pertanian, 13(1), 22-30.

Heriyanto, H. (2018). Permintaan Pangan Rumahtangga Provinsi Riau: Model Linear Approximate Almost Ideal Demand System. Jurnal Agribisnis, 20(2), 156-168.

Mahjoor, A. A. 2013. Technical, Allocative and Economic Efficiencies of Broiler Farms in Fars Province, Iran: a Data Envelopment Analysis (DEA) Approach. World Applied Sciences Journal, 21(10): 1427-1435

Mashkoor, M., S. Yahya and S.A. Ali. 2010. Tax Revenue and Economic Growth, an Empirical Analysis for Pakistan. World Applied Science Journal, 10(1): 1283-1289.

Omar, M.A.E. 2014. Technical and Economic Efficiency for Broiler Farms in Egypt. Application of Data Envelopment Analysis (DEA). Global Veterinaria, 12(5): 588593Pakage, S., Budi Hartono., Zaenal Fanani., Bambang Ali Nugroho. 2014. Analysis of Technical Efficiency of Poultry Broiler Business with Pattern Closed House System in Malang East Java Indonesia. Journal of Economics and Sustainable Development, 5(12): 16-23

Pourjafar, H., S. Kordrostami and S. Pourjafar. 2012. A Geometric Method in Data Envelopment Analysis to Obtain the Region of Efficiency.World Applied Sciences Journal, 18(12): 1870-1879.

Praditia, D., W. Sarengat., dan M. Handayani. 2015. Efisiensi Produksi Peternakan Ayam Pedaging Riski Jaya Abadi Kebumen Ditinjau Dari Efisiensi Manajemen,Teknis dan Ekonomis. Animal Agriculture Journal, 4(1): $75-80$
Rahimi, I. and R. Behmanesh. 2012. Improve Poultry Farm Efficiency in Iran: Using Combination Neural Networks, Decision Trees and Data Envelopment Analysis (DEA). International Journal of Applied Operational Research, 2(3): 69-84.

Rita, Y. 2009. Analisis Efisiensi Produksi Usaha Peternakan Ayam Ras Pedaging Pola Kemitraan dan Mandiri di Kota Palu Provinsi Sulawesi Tengah. Tesis Program Pascasarjana Universitas Diponegoro. [Tidak Dipublikasikan]

Saragih, B. 2000.Agribisnis Berbasis Peternakan: Kumpulan Pemikiran. IPB, Bandung

Soekartawi. 1997. Agribisnis Teori dan Aplikasinya. PT Raja Grafindo Persada, Jakarta

Sugiarto., Tedy Herlambang., Brastoro., Rahmat Sudjana dan Said Kelana. 2010. Ekonomi Mikro: Sebuah Kajian Komprehensif. Edisi Kelima. PT. Gramedia Pustaka Utama, Jakarta.

Sumiarsih, D. R. 2018. Analisis Efisiensi Usaha Peternakan Ayam Ras Pedaging Pola Kemitraan dan Pola Mandiri di Kecamatan Larangan Kabupaten Pamekasan. Maduranch, 3(1): 7-16

Tasman, A. 2008. Ekonomi Produksi: Analisis Efisensi dan Poduktivitas. Penerbit Chandra Pratama, Jakarta.

Wakhidati, Y. N., Sri Mastuti, Syarifuddin Nur dan Alief Einstein. 2017. Efisiensi Usaha Peternakan Ayam Broiler Di KabupatenMagelang. Prosiding Seminar Teknologi dan Agribisnis Peternakan V: Teknologi dan Agribisnis Peternakan Untuk Mendukung Ketahanan Pangan, Fakultas Peternakan Universitas Jenderal Soedirman.

Wahyudy, H. A., Khairizal, K., \& Heriyanto, H. (2019). Perkembangan Ekspor Karet Alam Indonesia. Dinamika Pertanian, 34(2), 1-8. 
